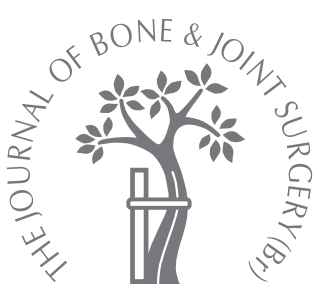

K.-J. Tan, C.-T. Lim, A. Y.-T. Lim

From the National University of Singapore, Singapore

\title{
The use of muscle flaps in the salvage of infected exposed implants for internal fixation
}

The treatment of infected exposed implants which have been used for internal fixation usually involves debridement and removal of the implant. This can result in an unstable fracture or spinal column. Muscle flaps may be used to salvage these implants since they provide soft-tissue cover and fresh vascularity. However, there have been few reports concerning their use and these have concentrated on the eradication of the infection and successful soft-tissue cover as the endpoint. There is no information on the factors which may influence the successful salvage of the implant using muscle flaps.

We studied the results and factors affecting outcome in nine pedicled muscle flaps used in the treatment of exposed metal internal fixation with salvage of the implant as the primary endpoint. This was achieved in four cases. Factors predicting success were age $<30$ years, the absence of comorbid conditions and a favourable microbiological profile. The growth of multiple organisms, a history of smoking and the presence of methicillin-resistant Staphylococcus aureus on wound cultures indicated a poor outcome. The use of antibiotic beads, vacuum-assisted closure and dressing, the surgical site, the type of flap performed and the time from primary surgery to flap cover were not predictive of outcome.

The management of fractures has been revolutionised by the use of internal fixation. Despite its advantages the occurrence of post-operative infection of the implant is a considerable complication. A resultant soft-tissue defect with an exposed implant will usually require radical debridement, irrigation, removal of the implant and subsequent measures to obtain soft-tissue cover.

In many situations, however, removal of the internal fixation may not be desirable since this may leave an unstable fracture which may require external fixation or an unstable spinal column with the danger of neurological compromise.

The salvage of infected exposed implants may be possible in some cases. ${ }^{1}$ Muscle flaps have an advantage by providing soft-tissue cover and the introduction of a fresh blood supply to the ischaemic and contaminated wound. ${ }^{2}$ However, there have been few reports on the salvage of infected internal fixation devices using muscle flaps. ${ }^{2,3}$ These have been mainly used to manage the soft-tissue defect after debridement and removal of the implant and not to attempt primary salvage of the implant. ${ }^{4,5}$ Reports of their use have concentrated on the outcome of absence of infection with successful soft-tissue cover, but have not focused on salvage of the implant as a primary outcome. They have mainly been descriptions of cases with a successful outcome and have not analysed factors which may contribute to the success or failure of retention of the implant without further evidence of infection.

We describe the results of the use of pedicled or free flaps performed for the salvage of infected, exposed implants. Age, the presence of comorbid conditions, the original pathology, the location of the soft-tissue defect, the time from the primary procedure to flap cover, the type of flap and the presence of associated micro-organisms were analysed as factors affecting the successful outcome of retention of implants with no further evidence of infection.

\section{Patients and Methods}

This was a retrospective case series involving eight patients (nine pedicled or free flaps). An independent physician (KJT) not involved in the management of the patients reviewed the notes of these patients. All the implants had been inserted for fixation of a fracture or stabilisation of the spine. The original injury had been deemed to be suitable for internal fixation without requiring soft-tissue cover. Complications subsequently occurred which led to exposure of the implant and treatment using a flap 
was undertaken in an attempt to salvage the internal fixation. The endpoint used in the assessment of the cases was the need for implants to be removed because of continuing infection after debridement, cover by the flap and an appropriate antibiotic regime. Success was defined as the absence of continuing clinical signs of infection with retention of the implants after cover by the flap, and failure as the need for removal of the implant because of continuing infection.

There were seven men and one woman with a mean age of 37.1 years (17.0 to 53.0). Seven had undergone fixation for traumatic fractures and one had undergone spinal decompression and stabilisation for vertebral metastasis secondary to pulmonary malignancy (Table I).

\section{Results}

All the patients had infected exposed implants, four on the lateral aspect of the calcaneum (Fig. 1), two at the medial side of the tibia (Fig. 2), one on the anteromedial side of the knee, one at the anterior clavicle and one over the spine. The mean time from the primary surgery to flap cover was 36.8 days $(8.0$ to 63.0$)$. The mean duration after wound breakdown to flap cover was 15.7 days (6.0 to 30.0$)$. The four calcaneal wounds were covered by sural flaps. Pedicled flaps based on the sternal head of pectoralis major and latissimus dorsi were used to cover the clavicular and spinal wounds, respectively. A medial gastrocnemius pedicled flap was used to salvage the implants on the anteromedial aspect of the knee. Free gracilis flaps were used for both tibial wounds (Table I).

The implants were successfully retained with no further clinical evidence of infection in four of the nine cases. One patient died from sepsis two months after the primary surgery and this was defined as a failure although the implants had been retained. In the other four failures the implants were removed because of persistent evidence of infection between 37 and 148 days after the primary surgery. Three of these patients required an additional two to three debridements. The fourth did not need further debridement (Table I). However, although it was necessary to remove the internal fixation in these four patients the flap survived.

Younger patients had a more favourable outcome with successful salvage of the implant occurring in the three youngest patients all of whom were under 30 years of age. The fourth patient with a successful outcome was 50 years of age.

The microbiological profile and the presence or absence of comorbid conditions were also found to be predictive of outcome. The presence of methicillin-resistant Staphylococcus aureus (MRSA) and of more than one type of organism was associated with a poor outcome. MRSA was present in six patients, in five of whom the attempt to salvage the implant failed. In four of these five patients more than one organism was grown from the wound cultures.

Most of the patients had no comorbid conditions, but two with diabetes and malignancy who had received perioperative steroids did not have a successful outcome. One patient had haemoglobin $\mathrm{H}$ disease, but his haemoglobin level on admission was more than $10 \mathrm{~g} / \mathrm{dl}$. He was admitted with a calcaneal fracture after a fall from a height and the $\mathrm{HbH}$ disease was not considered to be a significant comorbid factor. He had a successful outcome. Two patients were smokers and in both the flap failed with subsequent removal of the implant.

The use of antibiotic beads, vacuum-assisted closure dressing, the surgical site, the type of flap used and the time from the primary treatment to cover by a flap were not found to be predictive factors. The procedure was successful in two patients with calcaneal wounds, in one with a tibial wound and in one with a wound on the anteromedial aspect of the knee. Successful salvage of the implant was achieved in patients with flap cover at between eight and 63 days after primary surgery and at six to 30 days after the initial breakdown of the wound indicating that the timing of the procedure was not a factor in achieving success.

\section{Discussion}

The introduction and increasing application of internal fixation for fractures have revolutionised their management, achieving stabilisation of bone and soft-tissues and allowing early mobilisation, with an improved outcome. The occurrence of post-operative infection is a major disaster. It is usually treated by repeated wound exploration, debridement, and, if necessary, removal of the implant followed by the long-term administration of intravenous antibiotics. Even worse is the situation in which there is concurrent loss of soft-tissue cover resulting in an exposed, infected implant associated and a poor outcome. The traditional treatment includes wide debridement, vigorous antibiotic irrigation, removal of the implant and stable soft-tissue cover. However, removal of the implant is not always desirable since this would leave either an unstable fracture which may require external fixation for stabilisation or, in the case of the spinal column, instability and possible neurological compromise.

Flap cover in primary treatment has gained widespread acceptance in a large series of 532 patients. Godina ${ }^{6}$ found that early flap cover in primary trauma with a soft-tissue defect was associated with a lower rate of failure of the flap, a lower rate of post-operative infection, a shorter time to bone healing and a shorter mean length of hospital stay. Gopal et $\mathrm{al}^{7}$ also described radical debridement, internal fixation and soft-tissue cover as an initial procedure. This was termed the 'fix-and-flap' principle. In their series, the patients had a rate of union of $100 \%$, excluding four who required an amputation. The rate of superficial infection was $6 \%$ and of deep infection $9.5 \%$.

The salvage of infected, exposed implants after an initial period of internal fixation without flap cover is difficult, but may be possible with early recognition of infection, aggressive irrigation and debridement by stable wound cover. ${ }^{1}$ The local wound environment is usually ischaemic and contaminated, with a soft-tissue defect and the use of 
Table I. Details of the patients and the results

\begin{tabular}{|c|c|c|c|c|c|c|c|c|c|c|c|c|c|}
\hline Case & $\begin{array}{l}\text { Age } \\
\text { (yrs) }\end{array}$ & Gender & $\begin{array}{l}\text { Comorbid } \\
\text { conditions } \\
\text { and smok- } \\
\text { ing status }\end{array}$ & $\begin{array}{l}\text { Original } \\
\text { pathol- } \\
\text { ogy }\end{array}$ & $\begin{array}{l}\text { Primary } \\
\text { surgery } \\
\text { done* }\end{array}$ & $\begin{array}{l}\text { Details of } \\
\text { post-primary } \\
\text { surgery to } \\
\text { wound } \\
\text { breakdown } \\
\text { (days) }\end{array}$ & $\begin{array}{l}\text { Duration } \\
\text { of post- } \\
\text { wound } \\
\text { break- } \\
\text { down to } \\
\text { flap cover } \\
\text { (days) }\end{array}$ & $\begin{array}{l}\text { Duration of } \\
\text { post- } \\
\text { primary } \\
\text { surgery to } \\
\text { flap } \\
\text { cover } \\
\text { (days) }\end{array}$ & $\begin{array}{l}\text { Type of } \\
\text { pedicled/ } \\
\text { free flap } \\
\text { cover }\end{array}$ & $\begin{array}{l}\text { Length } \\
\text { of } \\
\text { follow- } \\
\text { up } \\
\text { (mths) }\end{array}$ & $\begin{array}{l}\text { Eventual } \\
\text { flap } \\
\text { survival }\end{array}$ & $\begin{array}{l}\text { Success/fail- } \\
\text { ure of implant } \\
\text { salvage }\end{array}$ & $\begin{array}{l}\text { Number } \\
\text { of opera- } \\
\text { tions } \\
\text { after } \\
\text { implant } \\
\text { removal }\end{array}$ \\
\hline 1 & 52 & $M$ & $\begin{array}{l}\text { Peri-opera- } \\
\text { tive } \\
\text { dexametha- } \\
\text { sone, } \\
\text { chronic } \\
\text { smoker }\end{array}$ & $\begin{array}{l}\text { Right } \\
\text { Pancoast } \\
\text { tumour } \\
\text { with } \\
\text { T2 cord } \\
\text { compres- } \\
\text { sion }\end{array}$ & $\begin{array}{l}\text { Laminec- } \\
\text { tomy } \\
\text { and decom } \\
\text { pression T1- } \\
3 \text {, posterior } \\
\text { - spinal } \\
\text { instrumenta- } \\
\text { tion C6 to T6 }\end{array}$ & 22 & 21 & 43 & $\begin{array}{l}\text { Latissimus } \\
\text { dorsi flap }\end{array}$ & 2 & $\begin{array}{l}\text { Died from } \\
\text { sepsis }\end{array}$ & $\begin{array}{l}\text { Died from sep- } \\
\text { sis }\end{array}$ & $-\mathrm{NA}^{\dagger}$ \\
\hline 2 & 53 & $\mathrm{M}$ & $\begin{array}{l}\text { Diabetes } \\
\text { hyperten- } \\
\text { sion }\end{array}$ & $\begin{array}{l}\text { Road- } \\
\text { traffic } \\
\text { accident. } \\
\text { Left clavi- } \\
\text { cle open } \\
\text { fracture }\end{array}$ & $\begin{array}{l}\text { lliac-crest } \\
\text { bone graft- } \\
\text { ing and } \\
\text {-plating for } \\
\text { nonunion }\end{array}$ & 27 & 16 & 43 & $\begin{array}{l}\text { Pectoralis } \\
\text { major } \\
\text { sternal head } \\
\text { pedicled flap }\end{array}$ & 18.6 & Yes & $\begin{array}{l}\text { Failure. } \\
\text { Implants } \\
\text { removed } 148 \\
\text { days post-pri- } \\
\text { mary surgery }\end{array}$ & Nil \\
\hline 3 & 48 & $\mathrm{M}$ & $\begin{array}{l}\text { Chronic } \\
\text { smoker }\end{array}$ & $\begin{array}{l}\text { Forklift } \\
\text { ran over } \\
\text { leg } \\
\text { Open } \\
\text { tibial } \\
\text { fracture }\end{array}$ & $\begin{array}{l}\text { ORIF plating } \\
\text { and iliac- } \\
\text { crest } \\
\text { bone graft- } \\
\text { ing }\end{array}$ & 17 & 6 & 23 & Free gracilis & 51.4 & Yes & $\begin{array}{l}\text { Failure } \\
\text { Implants } \\
\text { removed } 70 \\
\text { days post- } \\
\text { primary } \\
\text { surgery }\end{array}$ & 3 \\
\hline 4 & 35 & $\mathrm{M}$ & Nil & $\begin{array}{l}\text { Fall from } \\
\text { height } \\
\text { Bilateral } \\
\text { calcaneal } \\
\text { fractures }\end{array}$ & $\begin{array}{l}\text { ORIF both } \\
\text { calcanea }\end{array}$ & 12 & 17 & 29 & Sural flap & 25.6 & Yes & $\begin{array}{l}\text { Failure } \\
\text { Implants } \\
\text { removed } 37 \\
\text { days post-pri- } \\
\text { mary surgery }\end{array}$ & 2 \\
\hline 5 & 35 & $\mathrm{M}$ & Nil & $\begin{array}{l}\text { Fall from } \\
\text { height } \\
\text { Bilateral } \\
\text { calcaneal } \\
\text { fractures }\end{array}$ & $\begin{array}{l}\text { ORIF both } \\
\text { calcanea }\end{array}$ & 12 & 10 & 22 & Sural flap & 25.6 & Yes & $\begin{array}{l}\text { Failure. } \\
\text { Implants } \\
\text { removed } 37 \\
\text { days post- } \\
\text { primary } \\
\text { surgery }\end{array}$ & 3 \\
\hline 6 & 50 & $\mathrm{M}$ & $\begin{array}{l}\mathrm{HbH}^{\ddagger} \\
\text { disease }\end{array}$ & $\begin{array}{l}\text { Fall from } \\
\text { height } \\
\text { Right cal- } \\
\text { caneal } \\
\text { fracture }\end{array}$ & $\begin{array}{l}\text { ORIF } \\
\text { calcaneum }\end{array}$ & 14 & 30 & 44 & Sural flap & 14.7 & Yes & Success & NA \\
\hline 7 & 25 & $\mathrm{M}$ & Nil & $\begin{array}{l}\text { Road- } \\
\text { traffic } \\
\text { accident } \\
\text { Open } \\
\text { calcneal } \\
\text { fracture }\end{array}$ & $\begin{array}{l}\text { ORIF } \\
\text { calcaneum }\end{array}$ & 2 & 6 & 8 & Sural flap & 21.4 & Yes & Success & NA \\
\hline 8 & 17 & $\mathrm{M}$ & $\begin{array}{l}\text { None, previ- } \\
\text { ous tibial } \\
\text { plating }\end{array}$ & $\begin{array}{l}\text {-Fall } \\
\text { during } \\
\text { sports } \\
\text { game } \\
\text { Peripros- } \\
\text { thetic } \\
\text { fracture } \\
\text { of } \\
\text { tibial } \\
\text { plate } \\
\text { superior } \\
\text { edge }\end{array}$ & $\begin{array}{l}\text { Implant } \\
\text { removal } \\
\text { of previous } \\
\text { plate, ORIF } \\
\text { tibial } \\
\text { metaphyseal } \\
\text { locking plate } \\
\text { using MIPO } \\
\text { technique }\end{array}$ & 44 & 19 & 63 & Free gracilis & 17.8 & Yes & Success & NA \\
\hline 9 & 17 & $\mathrm{~F}$ & Nil & $\begin{array}{l}\text { Road- } \\
\text { traffic } \\
\text { accident } \\
\text { Open } \\
\text { fractures } \\
\text { of right } \\
\text { patella, } \\
\text { femur } \\
\text { lateral } \\
\text { condyle } \\
\text { and tib- } \\
\text { ial pla- } \\
\text { teau }\end{array}$ & $\begin{array}{l}\text { ORIF femo- } \\
\text { ral } \\
\text { condyle, } \\
\text { patella } \\
\text { and plating } \\
\text { of tibia }\end{array}$ & 40 & 16 & 56 & $\begin{array}{l}\text { Medial } \\
\text { gastrocne- } \\
\text { mius flap }\end{array}$ & 45.4 & Yes & Success & NA \\
\hline
\end{tabular}

* ORIF, open reduction and internal fixation; MIPO, minimally invasive plate osteosynthesis

† NA, not available

$\ddagger \mathrm{HbH}$, haemoglobin $\mathrm{H}$ disease 


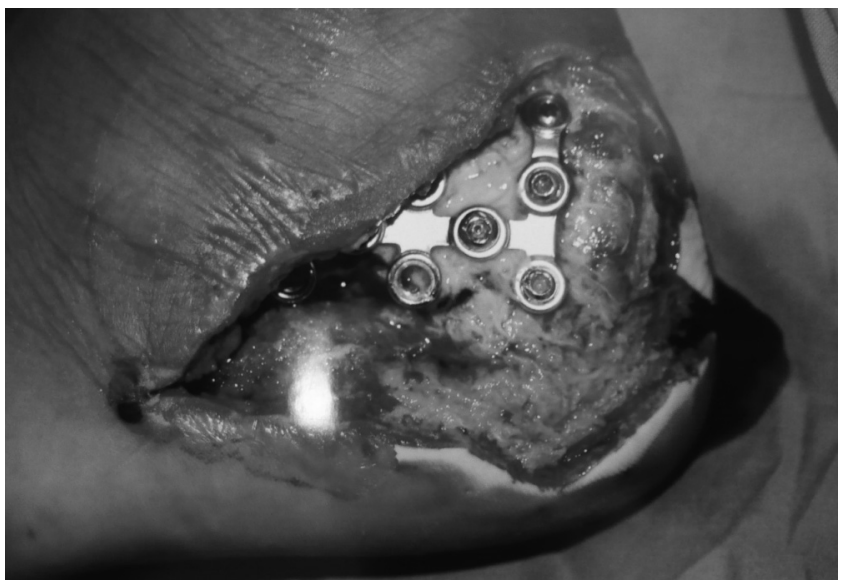

Fig. 1

Photograph of a lateral calcaneal wound before cover with a flap.

free muscle flaps conveys a considerable advantage in such conditions. ${ }^{2}$ Muscle and myocutaneous flaps have proved to be of great value in the reconstruction of problem wounds primarily because of their rich vascular supply and superior resistance to infection. ${ }^{8}$

There have only been few isolated reports of the salvage of infected implants by cover with a flap. ${ }^{9}$ These have been used more often to manage a soft-tissue defect after radical debridement and removal of the implant. ${ }^{4,5}$ Few authors have considered salvage of the implant to be the primary endpoint after the use of a flap. Significant reports on the use of pedicled and free flaps in the salvage of implants have been limited to wound breakdown resulting in exposure of total knee prostheses. ${ }^{10-12}$ Reports of the salvage of exposed infected implants used for the stabilisation of fractures by flaps have been restricted to descriptions of small collections of cases with a successful outcome. ${ }^{2,3}$

Although our series was a varied group, we have shown that salvage of infected exposed implants is possible by flap cover. Factors predicting outcome include age $<30$ years, an absence of comorbid conditions and the growth of a single organism on wound cultures. The presence of significant comorbid conditions such as diabetes, malignancy, the use of steroids and a history of smoking had a negative effect on outcome and, in particular, the growth of multiple organisms and the presence of MRSA on wound cultures were associated with an unsuccessful outcome. The use of antibiotic beads, the surgical site, the type of flap performed and the time from primary surgery to flap cover were not associated with a particular outcome.

Our method has some similarities to the fix-and-flap principle $^{7}$ but the latter involves immediate radical debridement of the wound to healthy tissue with simultaneous internal fixation and flap cover. Our cases were more challenging since they presented chronically and also required serial debridement before flap cover as the infection had more time

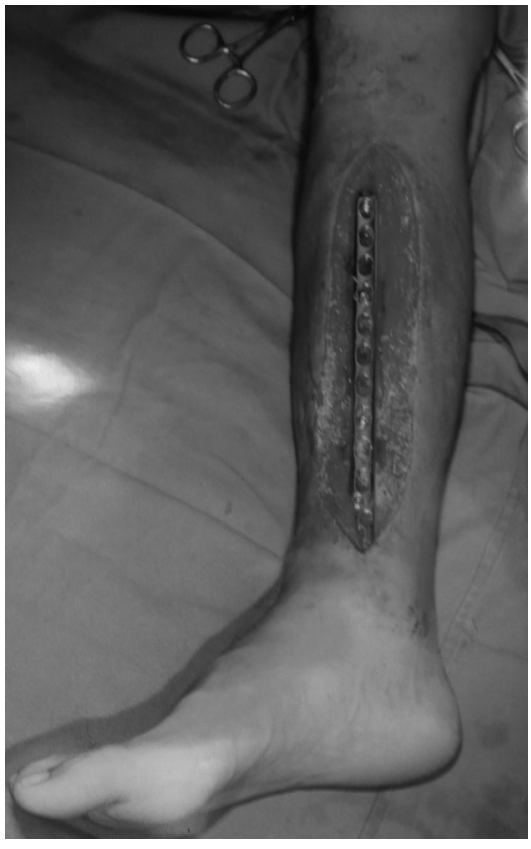

Fig. 2

Photograph of a lateral medial tibial wound before cover with a flap.

to become established. Bacteria have been known to form a biofilm and become resistant to antibiotics and superficial debridement in chronic wounds. ${ }^{13,14}$ In our cases this would have meant that immediate radical debridement such as in the fix-and-flap principle was less likely to succeed.

In our study, there was a varied time of six to 30 days from the initial presentation to flap cover. Early cover is generally beneficial but some of our cases only presented after breakdown of the wound following initial internal fixation. Singh et al, ${ }^{15}$ in a recent review of the literature, recommended early and aggressive debridement of all necrotic and non-viable tissue and the procurement of healthy margins before flap cover following wound breakdown after spinal instrumentation. The patients were initially treated with antibiotics and by debridement before a decision was made on flap cover. This led to a delay in cover of the exposed implants by a flap.

Wound care in our patients included debridement, vacuum-assisted closure dressing and the insertion of antibiotic beads. Of the four patients with successful salvage of the implant, two had vacuum-assisted closure dressings while only one of the five who needed removal of the implant had this treatment. These dressings ${ }^{16,17}$ have been shown to reduce oedema leading to an increase in localised blood flow and also to decrease the surface area of the wound. They also have been shown to be effective in the management of infected wound breakdown after spinal instrumentation. ${ }^{18}$ The use of antibiotic beads did not seem to affect the outcome of our patients. 
With an unsuccessful attempt at flap salvage of exposed implants further debridements will be needed in attempts to eradicate infection. In all cases of unsuccessful salvage, the flap survived and we feel that although there was a significant number of failures of implant salvage, the robust muscular flap cover may have assisted in the eradication of infection.

Successful surgical salvage of infected exposed devices for internal fixation can be achieved in some cases with adequate debridement and cover by a pedicled or free flap. Factors predicting success include age $<30$ years, the absence of comorbid conditions and a favourable microbiological profile. However, we recommend caution in patients with significant comorbid conditions, particularly a history of chronic smoking, the presence of MRSA and the growth of multiple organisms on wound cultures.

\section{Supplementary material}

ë A table showing the details of wound characteristics and care is available with the electronic version of this article on our website at www.jbjs.org.uk

No benefits in any form have been received or will be received from a commercial party related directly or indirectly to the subject of this article.

\section{References}

1. Gusenoff JA, Hungerford DS, Orlando JC, et al. Outcome and management of infected wounds after total hip arthroplasty. Ann Plast Surg 2002;49:587-92.

2. Lesavoy MA, Dubrow TJ, Wackym PA, et al. Muscle-flap coverage of exposed endoprostheses. Plast Reconstr Surg 1989;83:90-9.
3. Hultman CS, Jone GE, Losken A, et al. Salvage of infected spinal hardware with paraspinous muscle flaps: anatomic considerations with clinical correlation. Ann Plast Surg 2006;57:521-8.

4. Jones NF, Eadie P, Johnson PC, et al. Treatment of chronic infected hip arthroplasty wounds by radical debridement and obliteration with pedicled and free muscle flaps. Plast Reconstr Surg 1991;88:95-101.

5. Meland NB, Arnold PG, Weiss HC. Management of the recalcitrant total-hip arthroplasty wound. Plast Reconstr Surg 1991;88:681-5.

6. Godina M. Early microsurgical reconstruction of complex trauma of the extremities. Plast Reconstr Surg 1986;78:285-92.

7. Gopal S, Majumder S, Batchelor AG, et al. Fix and flap: the radical orthopaedic and plastic treatment of severe open fractures of the tibia. J Bone Joint Surg $[\mathrm{Br}]$ 2000;82-B:959-66

8. Mathes SJ, Alpert BS, Chang N. Use of the muscle flap in chronic osteomyelitis: experimental and clinical correlation. Plast Reconstr Surg 1982;69:815-29.

9. Cavadas PC, Landin L. Management of soft-tissue complications of the lateral approach for calcaneal fractures. Plast Reconstr Surg 2007;120:459-66.

10. Greenberg B, LaRossa D, Lotke PA, et al. Salvage of jeopardized total-knee prosthesis: the role of gastrocnemius muscle flap. Plast Reconstr Surg 1989;83:85-9.

11. Gerwin M, Rothaus KO, Windsor RE, et al. Gastrocnemius muscle flap coverage of exposed or infected knee prostheses. Clin Orthop 1993;286:64-70.

12. Adam RF, Watson SB, Jarratt JW, et al. Outcome after flap cover for exposed total knee arthroplasties: a report of 25 cases. J Bone Joint Surg [Br] 1994;76-B:750-3.

13. Costerton JW, Montanaro L, Arciola CR. Biofilm in implant infections: its production and regulation. Int J Artif Organs 2005;28:1062-8.

14. Subbiahdoss G, Kuijer R, Grijpma DW, et al. Microbial biofilm growth vs tissue integration: "the race for the surface" experimentally studied. Acta Biomater 2009:5:1399-404

15. Singh K, Samartzis D, Heller JG, et al. The management of complex soft-tissue defects after spinal instrumentation. J Bone Joint Surg [Br] 2006;88-B:8-15.

16. DeFranzo AJ, Argenta LC, Marks MW, et al. The use of vacuum-assisted closure therapy for the treatment of lower-extremity wounds with exposed bone. Plast Reconstr Surg 2001;108:1184-91.

17. Argenta LC, Morykwas MJ. Vacuum-assisted closure: a new method for wound control and treatment: clinical experience. Ann Plast Surg 1997;38:563-76.

18. Canavese F, Gupta S, Krajbich JI, Emara KM. Vacuum-assisted closure for deep infection after spinal instrumentation for scoliosis. J Bone Joint Surg [Br] 2008;90B:377-81 